\title{
From Property Right to Copyright: A Conceptual Approach and Justifications for the Emergence of Open Access
}

\author{
Nikos Koutras*
}

\begin{abstract}
This article relies on the premise that to understand the significance of Open Access Repositories (OARs) it is necessary to know the context of the debate. Therefore, it is necessary to trace the historical development of the concept of copyright as a property right. The continued relevance of the rationales for copyright interests, both philosophical and pragmatic, will be assessed against the contemporary times of digital publishing. It follows then discussion about the rise of Open Access (OA) practice and its impact on conventional publishing methods. The present article argues about the proper equilibrium between self-interest and social good. In other words, there is a need to find a tool in order to balance individuals' interests and common will. Therefore, there is examination of the concept of property that interrelates justice (Plato), private ownership (Aristotle), labour (Locke), growth of personality (Hegel) and a bundle of rights that constitute legal relations (Hohfeld). This examination sets the context for the argument.
\end{abstract}

\section{Introduction}

This article relies on the premise that to understand the significance of Open Access Repositories (OARs) it is necessary to know the context of the debate. Therefore, it is necessary to trace the historical development of the concept of copyright as a property right. The continued relevance of the rationales for copyright interests, both philosophical and pragmatic, will be assessed against the contemporary times of digital publishing, followed by a discussion about the rise of Open Access (OA) practice and its impact on conventional publishing methods.

The present article argues that there is a proper equilibrium between self-interest and social good. There is thus a need to find a tool that balances individuals' interests and the common will. This requires an examination of the concept of property that interrelates justice (Plato), private ownership (Aristotle), labour (Locke) and growth of personality (Hegel). This examination sets the context for the argument. In the literature the core notion of property (i.e. as a concept and its subject matter) is seen to stem from Aristotle's ideas about pri- vate property that lead to evolution, production and personal growth. Additionally, the concept of property has evolved from Plato's joint ownership theory to full liberal ownership theory and moved in the direction set by Aristotle. The concept of private property has been considered similarly by following philosophers with Aristotle's conception.

However, Plato's ideas about the concept of property for communal use is a more desirable model, which can justify the philosophy of OA. The origins of the notion of property lie in his philosophy; in accordance with his ideas, the concept of property was introduced as joint ownership in terms of social justice and, moreover, as a beneficial tool to support the growth of the whole republic - the ideal republic. He argues that there should not be private property and that, therefore, property under the 'umbrella' of joint ownership forms the appropriate factor for peace and justice. Aristotle, although a student of Plato, focuses on a more individualistic aspect; he contends that private property is more effective and will lead to improvement. It is obvious that he denies his teacher's (Plato's) rationale about joint ownership by signalising that such extreme unification is against the diversity of personal identity and against the benefit that everyone gathers through market exchange.

This leads to a discussion of Locke's philosophy, as he extends the concept of private property ownership by combining it with work. Locke claims that whatever work is produced by an individual becomes his/her property. This idea justifies the connection of ownership and creation. Specifically, in his work titled Second Treatise on Government, ${ }^{1}$ Locke proposes an explanation of the right by which an individual can claim to own one part of the world when, according to the Bible, God gave the world to human beings in common. Locke argues that individuals own themselves and thus their own labour. At this point, the connection between Aristotle's and Locke's logic is evident. Locke and Aristotle agree that private property is one of numerous intricacies. However, Locke contends that there is a more individualistic rationale for property ownership than does Aristotle. 
Further on, according to Hegel's views, the concept of property is used to comprehend it as a phase in the development of human kind and the growth of individual personality; thus, he extends the appropriate environment or surroundings of private property following Aristotle's and Locke's logic or reasoning. This chronological order provides an effective flow of thought that enables me to propose justifications for the emergence of $\mathrm{OA}$ as additional support to current copyright regimes.

From Aristotle's philosophy to modern times there are differences regarding traits of property and its ownership, as, one by one, philosophers added new features to their theories. Plato's argumentation about joint ownership was neglected. However, Plato's philosophy on property enables us to draw on his notions about communal property or joint ownership and its significance within OA. The argument of this article is based on Plato's logic, partly because later philosophers also implicitly support his ideas regarding communal use of property, as they highlight several unique aspects of community as a whole. ${ }^{2}$

The OA practice supports wider distribution of information resources. Therefore, when information and communication technologies are undergoing a 'revolution', it is imperative to go back to Plato's concept and argue that $\mathrm{OA}$ determines an instrument with benefits towards wide dissemination of information resources. Hence, there is a need to connect the emergence of copyright protection with developments in the concept of property. The same connections can justify the development of $\mathrm{OA}$ in contemporary times, as, for instance, balancing individual rights with the social good. The last part discusses $\mathrm{OA}$ in terms of an appropriate shift of existing copyright protection in the digital age, which leads to distribution of information and information accessibility. Also considered here is the question of whether open access could be an efficient way of enhancing the relationship between individuals' interests and the common will.

In the following section, the first subsection deals with the conceptualisation of property based on Plato's and Aristotle's views about property. This discussion traces the transition from public or communal property (Plato's perspective) to the understanding of property as an individual ownership right and the change in the understanding of private property that encourages personal developments (Aristotle's perspective). This helps to associate basic elements in the ideas of previous philosophers with the views of modern philosophers concerning the concept of property. The argument advances further in part two with a discussion that relies on modern philosophers' ideas (e.g., Locke and Hegel) about property as they argue about the connection between

2. This mutual philosophical consideration can be described as follows: Aristotle highlights individualism and self-interest, Locke proposes that property rights are individuals' natural rights and Hegel emphasises that all types of individuals' rights lie in property. ownership and the input of labour in order to possess actual property.

\section{Conceptual Framework of Property}

\subsection{Plato's Notions of Property}

Plato's ideas about property were related to his ideas about family, society and the republic. They also contain the origins of notions of patents. His ideas are explained below. In the period around 500 B.C. in Ancient Greece, some form of patent rights was recognised. For example, in the Greek city of Sybaris, patents were granted for the creation of unique culinary dishes. ${ }^{3}$ Encouragement was provided to those who introduced refinements in luxury; profits accruing from such endeavours were secured to the inventor by a patent for the period of one year. ${ }^{4}$ This kind of protection for one year illustrates that creative endeavours were encouraged in a manner that protected the whole market from monopolies. At the same time, one or more persons could enjoy an economic advantage in relation to their creative efforts. In this context, Plato's ideas are useful to describe an ideal republic in which only philosophers ought to keep private property in terms of justice. ${ }^{5}$ For the rest, he suggests that there should be joint ownership. ${ }^{6}$ The shape of Plato's ideal republic requires justice as its main purpose. ${ }^{7}$

Plato contends that owning private property leads to greed and lust. He claims that children should be taken from their biological parents and redistributed by the state to other parents; that is how he supports his arguments concerning private property and the right to 'own' a child. ${ }^{8}$ In other words, Plato does not believe in private property as such; he believes that, eventually, no one should own anything, except for the philosophers. ${ }^{9}$ Therefore, some scholars call Plato a proto-socialist or a proto-communist. In response, it can be said that this view of property was applied by Plato only to the guardian class and the auxiliaries for the purpose of focusing their attention on the ever-important matter of the state. It should not overshadow the fact that this was the first time that someone initiated a discussion about the

3. A. Rich, A Dictionary of Roman and Greek Antiquities (Nabu Press, 2010).

4. W. Smith, A Concise Dictionary of Greek and Roman Antiquities (Nabu Press, 2010).

5. C.H. Kahn, Plato and the Socratic Dialogue: The Philosophical Use of a Literary Form (Cambridge University Press, 1998).

6. M.S. Kochin, Gender and Rhetoric in Plato's Political Thought (Cambridge University Press, 2002).

7. L.H. Craig, The War Lover: A Study of Plato's Republic (University of Toronto Press, 1996); S. Rosen, Plato's Republic: A Study (Yale University Press, 2005); J. Lear, 'Allegory and Myth in Plato's Republic', in G. Santas (ed.), The Blackwell Guide to Plato's Republic (Blackwell Publishing Ltd, 2006) 25.

8. C.H. Zuckert, Plato's Philosophers: The Coherence of the Dialogues (University Of Chicago Press, 1st ed., 2009)

9. C. Zoller, 'Interpreting Plato's Dialogues (Review)', 45(3) Journal of the History of Philosophy 486 (2007). 
importance of private property, its content and how it was going to be used, as well as to explicate the main purposes for private ownership of property. ${ }^{10}$

Plato's ideas about private property are fundamentally affiliated with the concept of family, particularly with 'children', as he argues that having a child leads to greed and lust. However, as children grow into adults and, consequently, become active members of society, Plato's views about private property are, ultimately, not productive and are less humanitarian. Plato influenced his student, Aristotle, just as Socrates influenced Plato. However, each man's influence eventually moved in different directions. Plato believes that concepts such as property have a universal form - an ideal form - that led to his idealistic philosophy and ideal republic. Conversely, Aristotle believes that universal forms are not appropriately connected to each other and that thus each instance of an object has to be examined by itself. In the light of this logic, Plato is more interested in justifying communism of the elites based on joint ownership, whereas Aristotle is more interested in justifying a political order based on private property from an individual standpoint - something that is relevant to me and leads me to examine Aristotle's views on the concept of property.

\subsection{Aristotle's Philosophy and His Concept of Property}

Aristotle's views are particularly crucial because the entire structure of his thought had a great and even dominant influence on the economic and social thought of the Western world. Although Aristotle, in the Greek tradition, scorns moneymaking and is scarcely a partisan of laissez-faire, he sets forth a trenchant argument in favour of private property. ${ }^{11}$ Perhaps influenced by the private property arguments of another Greek philosopher, Democritus, Aristotle strongly attacks the concept of communism among the ruling class, as called for by Plato. ${ }^{12} \mathrm{He}$ denounces Plato's goal of the perfect unity of the state through communism by pointing out that the idea of such extreme unity militates against the diversity of mankind and against the reciprocal advantage that everyone reaps through market exchange. ${ }^{13}$

First, private property is more highly productive and will, therefore, lead to progress. According to Aristotle's view, goods owned in common by many people will receive little attention, since people will be guided main-

10. G.A. Press, 'Methods of Interpreting Plato and His Dialogues (Review)', 34(1) Journal of the History of Philosophy 135 (1996).

11. E. Brady, 'Aristotle, Adam Smith and the Virtue of Propriety', 8(1) Journal of Scottish Philosophy 79 (2010); M.J. Calkins and P.H. Werhane, 'Adam Smith, Aristotle, and the Virtues of Commerce', 32(1) The Journal of Value Inquiry 43 (1998).

12. H.W. Spiegel, The Growth of Economic Thought (Duke University Press, 1991); J. Brunschwig, A Guide to Greek Thought: Major Figures and Trends (Harvard University Press, 2003); L. Nolan, Primary and Secondary Qualities: The Historical and Ongoing Debate (Oxford University Press, 2011).

13. A.D. Bloom, The Republic of Plato (Basic Books, 1991); R. Mayhew, Aristotle's Criticism of Plato's Republic (Rowman \& Littlefield Publishers, 1997). ly by their own self-interest. ${ }^{14}$ In contrast, people will devote the greatest interest and care to their own property. Aristotle connects creation and production with progress, and this connection provides a justification for the need to extend Plato's idea of private property in goods to creative endeavours.

Second, Aristotle responds to one of Plato's arguments for property: that it is conducive to social peace as no one will be envious, or try to grab the property, of another. Aristotle argues that property will lead to continuing and intense conflict, as each will complain that he has worked harder and obtained less than others who have done little and taken more from the common store. Further, Aristotle declares that not all crimes or revolutions are powered by economic motives. As Aristotle trenchantly puts it, 'men do not become tyrants in order that they may not suffer cold'. ${ }^{15}$ Aristotle's statements make it evident that in his view creators have to be rewarded and protected in regards to their work and contribution to the whole society. In light of this rationale, it is imperative to create an appropriate form of property to protect intellectual creations. Plato's concept of property has distinct negative aspects and easily causes injustice and conflict regarding creators' profits. ${ }^{16}$ Thus, Aristotle's arguments help justify the need to transform Plato's idea of property and expand its focus on goods to include creative efforts.

Aristotle provides a third argument against Plato's concept of property. He says that private property is plainly embedded in man's essence. His admiration of personality or individuality, money and property is interconnected with a natural love of exclusive ownership. Fourth, Aristotle specifies that private property has existed always and everywhere. ${ }^{17}$ To enforce communal property on society would be to disregard the record of human experience and to leap into the new and untried. Abolishing private property would probably create more problems than it would solve. Eventually, Aristotle weaves together his economic and moral theories by providing the brilliant insight that only private property furnishes people with the opportunity to act morally; for example, to practice the virtues of welfare and charity. The compulsion of communal property would destroy that opportunity. To sum up, according to Aristotle, the concept of private property constitutes a means of wealth, production and justice and should thus be protected. Although critical of moneymaking, ${ }^{18}$ Aristotle

14. C. Ash, 'Social-Self-Interest', 71(2) Annals of Public and Cooperative Economics 261 (2000); I. Maitland, 'The Human Face of Self-Interest', 38(1/2) Journal of Business Ethics 3 (2002); S. Besson and J.L. Martí, Deliberative Democracy and Its Discontents (Ashgate Publishing, Ltd., 2006); H.O. Rocha and S. Ghoshal, 'Beyond Self-Interest Revisited', 43(3) Journal of Management Studies 585 (2006); C. De Dreu and A. Nauta, 'Self-Interest and Other-Orientation in Organizational Behavior: Implications for Job Performance, Prosocial Behavior, and Personal Initiative', 94(4) Journal of Applied Psychology 913 (2009).

15. Aristotle, Politics (Digireads.com Publishing, 2004) 25.

16. H.-H. Hoppe, The Ethics and Economics of Private Property (2004).

17. M.N. Rothbard, Aristotle on Private Property and Money (2009).

18. S. Meikle, 'Aristotle's Economic Thought' (1997), available at: https:// ideas.repec.org; H.C. Mansfield Jr., 'Marx on Aristotle: Freedom, Money, and Politics', 34(2) The Review of Metaphysics 351 (1980); 
still opposes any limitation on an individual's accumulation of private property. Instead, in his view, education should teach people to voluntarily curb their rampant desires and thus lead them to limit their own accumulation of wealth. Despite his cogent defence of private property and opposition to coerced limits on wealth, the aristocrat, Aristotle, is fully as scornful of labour and trade as his predecessors.

Aristotle created great trouble for the future by morally condemning the lending of money and decrying the charging of interest as 'unnatural'. ${ }^{19}$ Since money cannot be used directly and is employed only to facilitate exchanges, it is 'barren' and cannot itself increase wealth. Therefore, the charging of interest, which Aristotle thought to imply a direct productivity of money, was in his view contrary to nature and thus strongly condemnable.

Yet the classical philosophy of Aristotle was, in due course, followed by the development of liberal philosophy. Locke was one of the foremost liberal thinkers of his time, and his ideas on property inform our contemporary understanding. It follows examination of Aristotle's conception as regards private property in the context of Locke's ideas about property. It is instructive that when Locke's political theory was first published in 1689 , the impressive authority of Aristotle stood ready to defeat it. When it was confirmed that the renowned author of An Essay Concerning Human Understanding had also written the anonymously published Tmo Treatises of Government, Locke was broadly taken to show a distinctive kind of political theory based on individual rights and social contract; this type of account of politics has in many ways rested on Aristotle.

\section{From Lands and Goods to Creative Efforts}

\subsection{Locke's Philosophy on Property}

An analysis of Locke's philosophy will help to highlight the importance of work in relation to property ownership. To begin with, it should be noted that both Locke and Aristotle acknowledge that the issue of private property is fraught with intricacies. Though both philosophers sketch disparate interpretations on how land should be distributed among people, Locke puts forward a more individualistic notion of property ownership than does Aristotle. Specifically, in his Second Treatise on Government, ${ }^{20}$ Locke provides an answer to the question, By what right can an individual claim to own one part of the world when, according to the Bible,

S. Zarlenga, 'The Lost Science of Money', 16(5) European Business Review (2004)

19. I. van Staveren, The Values of Economics: An Aristotelian Perspective (Routledge, 2013); R. Kraut and S. Skultety, Aristotle's Politics: Critical Essays (Rowman \& Littlefield, 2005).

20. J. Locke, Two Treatises of Government (2013); J. Locke, Second Treatise of Government: An Essay Concerning the True Original, Extent and End of Civil Government (John Wiley \& Sons, 2014)
God gave the world to human beings in common? In this work, Locke argues that individuals own themselves and thus their own labour. Accordingly, he argues that individual property rights are natural rights. It is evident that this idea is similar to Aristotle's, which did not support Plato's idea concerning joint ownership.

Following this argument, it is plausible that when individual labours and the outcome of this work is the creation of tangible objects, those objects become his property. Political philosopher Robert Nozick calls this idea the Lockean proviso. Further, according to Locke, the labourer has to hold a natural property right in the resource itself as the exclusive ownership was immediately appropriate for production. In addition, in the context of the connection of right on property with production, Locke clarifies that, in accordance with his philosophy, the concept of property illustrates exclusive rights on abstracts, especially creative endeavours, as he interconnects ownership with production.

Locke's theory on property can be examined as an expansion of Aristotle's main argument regarding private property. Locke argues that individuals can acquire full property rights over moveable and non-moveable parts of earth in a state of nature. The terms 'moveable' and 'non-moveable' are, in other words, 'tangible' and 'intangible' abstracts comprising notions, ideas, innovations, thoughts and, in general, intellectual creations. In regard to Locke and his contribution to theories of property, he expands on Aristotle's concept by stating that everyone owns a property, to which nobody else has any right. Admittedly, Aristotle's argument differs from Locke's in that Aristotle opined that those with private property should share it. Locke disputed this idea, arguing that one should only acquire as much property as is appropriate; he or she should not gather endlessly. Hence, Locke is Aristotle's successor concerning the development of the concept of property and offers the original point for justifying moving from private property in goods to property in creative endeavours. Locke's philosophy on property is followed by Hegel's theory, which can also be considered a further successor, as Hegel developed these ideas about property and made them into a natural right. Hegel's philosophy of property is discussed in the following subsection.

\subsection{Hegel's Philosophy of Property}

There are several approaches and varied definitions of property from a philosophical perspective; regardless of these differences, the element common to the concept of property is that it is treated as a means rather than as an end. In most theories of property, it is regarded as a means to the good life - as a term for gaining freedom or as a term for the recognition of a human being. ${ }^{21}$ Hegel follows Locke's rationale regarding the relationship between the individual and property; he argues that property is the embodiment of personality. Further, his

21. M.J. Radin, Reinterpreting Property (University of Chicago Press, 1993); D. Resnik, 'A Pluralistic Account of Intellectual Property', 46(4) Journal of Business Ethics 319 (2003); C. May, The Global Political Economy of Intellectual Property Rights: The New Enclosures? (Routledge, 2013). 
view can be seen as extending Locke's notions regarding private property, in as much as in claiming that property is the embodiment of personality, he transforms it into a natural right.

Simultaneously, he argues that the basis of individual rights lies in property. Property is not merely material acquisition, as it is central to an individual's assertion of identity and personality, and thus Hegel follows the same logic as Locke. What is more, Hegel says that property comprises both material and non-material aspects - in other words, tangible and intangible abstracts. Since Aristotle introduced private ownership as an aspect of self-interest, it encouraged philosophers like Locke and Hegel to further develop this issue and argue that property rights are natural rights and embodiments for personal growth, respectively. Suffice it to say that individuals' notions and self-interests are inherently distinguished from intellectual creation. From this mutual philosophical consideration, intellectual creation should be secured and protected as an additional instrument that accomplishes the move from property in goods to personal creations.

According to Hegel, property is an expression of ourselves and the 'location' where an individual can claim rights and state that 'this is mine' - a claim that others respect. $^{22}$ The system of private property establishes individuality via contract and exchange. Based on this point, Hegel justifies the inevitable links among property, growth of personality and profits that stem from the aspect of self-interest. Contract demonstrates ownership through institutionalised patterns of mutual respect of individual rights and commitments. Economic life governed by free exchange of goods is based on an institutionalised notion of the individual as having some claim to recognition as a right-bearing person. If an exchange market is to operate effectively, economic actors have to identify universal standards by which a person can claim to own property. Established patterns of mutual recognition in the modern economic sphere are embodied in economic actors and depict a 'common will'. ${ }^{23}$

As a result, the individual has no social traits and thus no reference to the social environment. This means that individuals have no private/personal life with features

22. D. Knowles, 'Hegel on Property and Personality', 33(130) The Philosophical Quarterly 45 (1983); M. Salter, 'Justifying Private Property Rights: A Message from Hegel's Jurisprudential Writings', 7(3) Legal Studies 245 (1987); H.-C. Schmidt am Busch, ‘Personal Respect, Private Property, and Market Economy: What Critical Theory Can Learn from Hegel', 11(5) Ethical Theory and Moral Practice 573 (2008); A. Chitty, 'Recognition and Property in Hegel and the Early Marx', 16(4) Ethical Theory and Moral Practice 685 (2013).

23. J.R. Hollingsworth and R. Boyer, Contemporary Capitalism: The Embeddedness of Institutions (Cambridge University Press, 1997); C. Knill and D. Lehmkuhl, 'Private Actors and the State: Internationalization and Changing Patterns of Governance', 15(1) Governance 41 (2002); K. Nicolaidis and G. Shaffer, 'Transnational Mutual Recognition Regimes: Governance without Global Government', 68(3/4) Law and Contemporary Problems 263 (2005); W. Zhang et al., ‘Local Gabor Binary Patterns Based on Mutual Information for Face Recognition', 7(4) International Journal of Image and Graphics 777 (2007); C. Shan, S. Gong \& P.W. McOwan, 'Facial Expression Recognition Based on Local Binary Patterns: A Comprehensive Study', 27(6) Image and Vision Computing 803 (2009). to be integrated into society, such as a marriage and/or family with/without children, and thus no social reference. ${ }^{24}$ Therefore, rights demonstrated by Hegel's idea of private property are abstract rights and engage individuals as universal subjects without specific features. ${ }^{25}$ In addition, morality is called by Hegel the system of mutual recognition and abstract right. Hegel tries to merge various features of his philosophy and social views into a general declaration about the nature of modernity. ${ }^{26} \mathrm{He}$ traces a contemporary conception of individuality and of the individual as the agent of rights to modern social, economic and political institutions. To Hegel, morality is the subjective part of the mutual social commitments that are politically institutionalised in contracts and economic markets. Therefore, individuals experience mutual commitments as a moral obligation to respect abstract rights as ideals or a vision of good based on mutual recognition of abstract rights.

From the perspective of freedom and in accordance with Hegel's philosophy, where emphasis is placed on human needs, property is the first component of freedom and, therefore, is in itself a substantive end. Following this notion, Hegel highlights that if possession, as power over things, is simply pursued to satisfy self-interest, then possession is the means of satisfying these sorts of needs. However, according to Hegel, satisfaction of human needs is the aspect of mediation regarding recognition of the subject as a free agent. In this manner, power over things appears as a means for the growth of individual personality. Therefore, this justification represents the importance of an effective interconnection among self-interest, property and personal progress or individual advancement.

Accordingly, Hegel claims that property is the manifestation of the individual's effort to deploy his or her powers and come to self-consciousness by the appropriation of his or her environment. ${ }^{27}$ Consequently, Hegel's task is not to provide a justification for property, but rather to comprehend and understand it as a phase in the production of the human mind. It is also the case that any effort to justify property in the context of Plato's ideas regarding joint ownership will not be suitable for Hegel, as he ignores the role that property plays in the growth of self-awareness among individuals. So long as property is the manifestation of one's will, it is appropriate to make clear that the substantial relationship between the willing subject and what should be individual's property is a procedure that should rely on self-determination.

24. A. Honneth, The Pathologies of Individual Freedom: Hegel's Social Theory (Princeton University Press, 2010).

25. G.W.F. Hegel, Hegel: Elements of the Philosophy of Right (Cambridge University Press, 1991); R. Cropanzano et al., 'Self-Enhancement Biases, Laboratory Experiments, George Wilhelm Friedrich Hegel, and the Increasingly Crowded World of Organizational Justice', 58(2) Journal of Vocational Behavior 260 (2001)

26. F. Hegel, The Philosophy of Right (Hackett Publishing, 2015).

27. R. Teichgraeber, 'Hegel on Property and Poverty', 38(1) Journal of the History of Ideas 47 (1977), at 47; A Theory of Property (Cambridge University Press, 1990); J.L. Schroeder, 'Unnatural Rights: Hegel and Intellectual Property', 60 University of Miami Law Review 453 (2005), at 453-456; May, above n 21, at 45-47 
Given Hegel's conceptualisation, it could be argued that intellectual property (IP) demonstrates individuals' ways of thinking and that it is thus necessary to clarify that when someone participates in a process where notions or thoughts develop in accordance with subliminal willingness. Hence, Hegel's ideas regarding comprehension of property can be considered a phase in the evolutionary process of the human mind.

From the foregoing discussion, it is evident that Plato, Aristotle, Locke and Hegel have developed the concept of property from communal property to individual ownership. Simultaneously, the justifications for ownership have expanded the concept of property from physical to intellectual goods. Thus, the concept of private property as a natural right gradually lends itself to the growth of notions regarding the elements of such a right.

\subsection{The Extension of Property to Intellectual Efforts: Justifications}

An important form of property in contemporary society is IP, which refers to original expressions of thought and new applications of ideas. ${ }^{28}$ The efforts to recognise and protect IP and the relevant markets in such IP have developed considerably over the course of this century. If anything, the effects of ongoing information and technology (IT) advancements point to the influence of intellectual creations and the corresponding desire to protect the economic and intellectual aspects of the same. ${ }^{29}$ Thus, in many ways, IP is justified as a kind of property. This comprises a vast area of specialist knowledge, and several salient issues could be identified. The following discussion is not meant to be an exhaustive analysis of all the relevant issues in this regard. Under this technological growth and progress, another aspect of property that should be considered is related to actual profits, as the concept of creation can be associated with such profits. ${ }^{30}$

A notable scholar in the area of IP theories is Robert Merges, who claims that property does have a future. In addition, he states that if property demonstrates a proper respect both for individual proprietors and the social needs, it can contribute beneficially to a well-organised sociopolitical framework. ${ }^{31}$ As long as modern society's profitable resources come to be intangible, this capacity will gradually be served by the crucial part of property we call IP. ${ }^{32}$ Accordingly, Merges clearly sets out the basic features of a workable justification of IP, which are as follows: (a) properties' creative labour in accordance

28. M.A. Lemley, 'Property, Intellectual Property, and Free Riding', 83 Texas Law Review 1031 (2004).

29. N. Kumar, 'Intellectual Property Rights, Technology and Economic Development: Experiences of Asian Countries', 38(3) Economic and Political Weekly 209 (2003); L. Yang and K.E. Maskus, 'Intellectual Property Rights, Technology Transfer and Exports in Developing Countries', 90(2) Journal of Development Economics 231 (2009).

30. E. Arezzo, 'Struggling around the Natural Divide: The Protection of Tangible and Intangible Indigenous Property', 25 Cardozo Arts \& Entertainment Law Journal 367 (2007).

31. R.P. Merges, Justifying Intellectual Property (Harvard University Press, 2011).

32. I. Mgbeoji, 'Justifying Intellectual Property', 50 Osgoode Hall Law Journal 291 (2012) with creative work is recognised and rewarded with true legitimate rights, and hence work from hourly wages is converted into a freestanding economic asset whenever possible; (b) grant of real rights, though not absolute rights, and within this element the creator's contribution is acknowledged by granting IP rights, but society's contribution to creative work is also acknowledged; and (c) accommodation of consumers' and users' necessities by facilitating and encouraging cost-effective and easy IP permission and licensing tools, combined with plain methods that allow binding dedication of rights to the public benefit. This last element of Merge's justification for IP serves as additional justification for OA practice. In the contemporary discourse of IP, the economic aspects of IP outweigh all other considerations. Therefore, it is imperative that the economic justifications of IP be addressed. This analysis could provide an additional factor in determining reasons for which the notion of property may be extended to creative endeavours. Not surprisingly, economists explore ways of allocating scarce resources efficiently to unlimited wants and realise that IP rights are a plausible way of dealing efficiently with scarcity. ${ }^{33}$ Another significant justification is that of utilitarianism; proponents argue that technological inventions are utilitarian works and, therefore, the principal economic theory applied is about utilitarianism. Moreover, utilitarian theorists generally endorse the creation of IP rights as an appropriate instrument to foster innovation. ${ }^{34}$ Hence, it is acknowledged that freedom of expression and creation and dissemination of information - and its protection - ought to coexist to support effective outcomes, such as innovation. This justification illustrates the importance of creators' rights and a recognition that such efforts enhance social evolution; thus, creative efforts should be protected and shared. ${ }^{35}$

However, a host of authors who have pursued economic analyses of IP have relied on the 'Kaldor-Hicks' criterion that advises lawmakers to develop a system of regulations that maximises aggregate welfare measured by end users' ability and willingness to pay for the goods and services in relation to information. Thus, three different economic justifications dominate the literature. First, incentive theory is the most common; it claims that the optimal doctrine is the one that maximises the difference between a) the current discounted value to end users of the intellectual products whose creation is

33. M.P. Pugatch, The International Political Economy of Intellectual Property Rights (Edward Elgar Publishing, 2004); M.P. Pugatch, The Intellectual Property Debate: Perspectives from Law, Economics and Political Economy (Edward Elgar Publishing, 2006).

34. P.S. Menell, 'Intellectual Property and the Property Rights Movement', 30 Regulation 36 (2007); P.S. Menell, 'The Property Rights Movement's Embrace of Intellectual Property: True Love or Doomed Relationship?', UC Berkeley Public Law Research Paper No. 965083 (2007).

35. R. Landry, N. Amara \& M. Lamari, 'Does Social Capital Determine Innovation? To What Extent?', 69(7) Technological Forecasting and Social Change 681 (2002); D. Lane et al., Complexity Perspectives in Innovation and Social Change (Springer Science \& Business Media, 2009); S.J. Guastello, Chaos, Catastrophe, and Human Affairs: Applications of Nonlinear Dynamics to Work, Organizations, and Social Evolution (Psychology Press, 2013). 
induced by holding out to creators and inventors the carrot of monopoly power, and b) the ensemble detriments generated by such a system of incentives. In other words, this theory urges governmental lawmakers to establish or further develop IP protection when doing so would help end users by stimulating creative efforts more than it would hurt them by constricting their access to intellectual products or raising their taxes.

The second is the economic justification, which is based on patent regimes that reduce rental dissemination. Accordingly, its objective is to eliminate or reduce the tendency of IP rights to advance duplicative or uncoordinated inventive activity. Economic waste of this sort can occur at three stages in the inventive process.

Third, it is indispensable to realise that copyright and patent systems play crucial roles in letting potential producers of intellectual products know what end users want; hence, they channel productive outcomes in directions most likely to enhance end users' welfare. Based on this rationale, sales and licences will ensure that goods get into the hands of people who need them and can pay for them. Only under specific circumstances in which transaction costs would prevent such voluntary exchanges should the holders of IP rights be denied total scrutiny in relation to the uses of their works.

This overview of the economic rationales of IP rights needs to be related to the wider issue of whether the products of creative efforts can even be characterised as property. At this point, it is logical for me to ask how the concept of property ownership has informed the development of notions of IP. IP refers to the rights associated with the expression of an idea, or to other abstract objects. ${ }^{36}$ In other words, IP indicates 'goods' created from our mind. Well-known types of IP rights comprise patents, trademarks and copyrights. In general, IP law supports exclusive rights to the appropriator over the use of IP and its aforementioned 'goods'. Below it is argued that the notion of IP rights was originally created to protect inventors and scientists, aiming to simultaneously protect creative procedures and benefit society. However, by amplifying the 'shield' of protection, this concept caused the opposite result. A few alternative initiatives to protect IP with less emphasis on trade emerged in the early nineties as a response to the progressively high level of capitalisation of IP rights.

\section{The Historical Growth of Copyright as Property Right}

In this part, the growth of copyright as property right is traced by examining the historical evolution of copyright from being considered property of goods to being considered property of creative endeavours with legal protection. It follows the connection of the Renaissance

36. D.E. Bouchoux, Intellectual Property: The Law of Trademarks, Copyrights, Patents, and Trade Secrets (Cengage Learning, 2012). developments with the creation of the printing press and explains how these resulted in the necessity for conceptualising IP and then protecting it through laws. Additionally, the Renaissance period was distinguished by a great revolution regarding intellectual creations, and, therefore, the concept of legitimate protection from relevant works emerged. This revolution laid the basis for the growth of the printing press industry. Consistently with the argument made in this article, this growth will lend further support to the claim that it is necessary to reform the concept of copyright to property right.

The following discussion is divided into six parts. The first part discusses the importance of the Renaissance and the rapid growth of intellectual creations, which indicated the end of medievalism and the beginning of the new age that would eventually introduce the law and economy of copyright. The second part looks at printing and publishing in Europe during the fifteenth century, when two advances illustrate a stage in the growth of copyright. In the third part, Speyer's monopoly, ${ }^{37}$ which was introduced in Venice, and the English printing culture are considered as two issues that stand out during the Renaissance period. The fourth part analyses the Statute of Anne, the first official copyright regime, which signifies the introduction, for the first time, of an intellectual protection regime that translates the concept of copyright into a property right. The fifth part considers the significance of the Berne Convention as an international agreement governing copyright. The last part examines the significance of the Trade-Related Aspects of Intellectual Property Rights (TRIPS) Agreement administered by the World Trade Organization (WTO). The TRIPS Agreement introduced IP law into the international trading system for the first time and remains the most comprehensive international agreement on IP. ${ }^{38}$ It provides the background for the discussion in subsequent chapters.

\subsection{Renaissance Period}

In the middle of the fourteenth century, Black Death, one of the most devastating pandemics in human history, swept through Europe, killing one-third of the population. ${ }^{39}$ Every institution of the medieval world was disconcerted, setting peasants free from feudal commit-

37. C.L.C.E. Witcombe, Copyright in the Renaissance: Prints and the Privilegio in Sixteenth-Century Venice and Rome (BRILL, 2004); C. Geiger, Criminal Enforcement of Intellectual Property: A Handbook of Contemporary Research (Edward Elgar Publishing, 2012).

38. C.M. Correa, Intellectual Property Rights, the WTO and Developing Countries: The TRIPS Agreement and Policy Options (Zed Books, 2000); F.M. Abbott, 'The Doha Declaration on the TRIPS Agreement and Public Health: Lighting a Dark Corner at the WTO', 5 Journal of International Economic Law 469 (2002); D. Matthews, Globalising Intellectual Property Rights: The TRIPS Agreement (Routledge, 2003); C. Deere, The Implementation Game: The TRIPS Agreement and the Global Politics of Intellectual Property Reform in Developing Countries (Oxford University Press, 2008).

39. M. Dols, 'The Black Death in the Middle East'; D. Raoult et al., 'Molecular Identification by "Suicide PCR" of Yersinia Pestis as the Agent of Medieval Black Death', 97(23) Proceedings of the National Academy of Sciences 12800 (2000); P. Ziegler, The Black Death (Faber \& Faber, 2013). 
ments. ${ }^{40}$ It was almost a century after the eruption of the Black Death that innovation in printing processes appeared, which, more than any other event, pointed to the end of medievalism and played a crucial role in the growth of the Renaissance. Moreover, it was the sign of the beginning of the new age that would finally introduce the law and economy of copyright. ${ }^{41}$

In 1439, Johannes Gutenberg, a German blacksmith, goldsmith, publisher and printer, introduced printing to Europe. ${ }^{42}$ His invention was a mechanical moveable type of printing, which shifted society as a whole and illustrates why it is regarded as the most crucial event of the modern period. ${ }^{43}$ Notions, considerations and discussions stimulated minds across Europe and a trend of publishing came into being. The literate people of any class could publish pamphlets and even books in their own language. ${ }^{44}$ It is worth noting that the first books printed in Europe were block books, with each page cut from a single block of wood, and usually these books were produced in two colours. ${ }^{45}$ Additionally, the procedure of cutting letters into the wood was labour intensive, and so books were only a few pages thick. ${ }^{46}$

As years passed by, another German goldsmith, Johannes Gutenberg, invented a more convenient process of printing by creating punches and casting styles of letters that permitted book printing within a more effective moveable form. Imitations of Gutenberg's printing press spread rapidly through Europe, and by the end of the century the publishing industry across Europe printed prolifically. The first printed European creation in moveable form is a papal indulgence of 1454

40. E. Brown, 'The Tyranny of a Construct: Feudalism and Historians of Medieval Europe', 79(4) The American Historical Review 1063 (1974); B. Stein, 'Politics, Peasants and the Deconstruction of Feudalism in Medieval India', 12(2/3) The Journal of Peasant Studies 54 (1985); J. Bean, From Lord to Patron: Lordship in Late Medieval England (Manchester University Press, 1989); J.L. Forgeng and J.L. Singman, Daily Life in Medieval Europe (Greenwood Publishing Group, 1999); F. Oakley, Politics and Eternity: Studies in the History of Medieval and Early Modern Political Thought (BRILL, 1999); J. Canning, A History of Medieval Political Thought: 300-1450 (Routledge, 2014).

41. W.M. Landes and R.A. Posner, The Economic Structure of Intellectual Property Law (Harvard University Press, 2009); R. Bowker, Copyright: Its History and Its Law (2012).

42. E.L. Eisenstein, The Printing Revolution in Early Modern Europe (Cambridge University Press, 2005); J. Kostylo, 'From Gunpowder to Print: The Common Origins of Copyright and Patent', in Privilege and Property: Essays on the History of Copyright (Open Book Publishers, 2010).

43. A. Briggs and P. Burke, Social History of the Media: From Gutenberg to the Internet (Polity, 2010); C. Reed, Gutenberg in Shanghai: Chinese Print Capitalism, 1876-1937 (UBC Press, 2011); M. McLuhan et al., The Gutenberg Galaxy: The Making of Typographic Man (University of Toronto Press, 2011).

44. C. Suhr, 'Publishing for the Masses: Early Modern English Witchcraft Pamphlets', 113(1) Neuphilologische Mitteilungen 118 (2012).

45. R. Chartier, The Order of Books: Readers, Authors, and Libraries in Europe Between the Fourteenth and Eighteenth Centuries (Stanford University Press, 1994); E. Buringh and J.L. Van Zanden, 'Charting the "Rise of the West": Manuscripts and Printed Books in Europe, A LongTerm Perspective from the Sixth through Eighteenth Centuries', 69(02) The Journal of Economic History 409 (2009).

46. L. Febvre and H.-J. Martin, The Coming of the Book: The Impact of Printing 1450-1800 (Verso, 1997). that was created in Mainz. ${ }^{47}$ In the 1460 s, German printers established workshops in Venice, Rome and Basel, which were under German dominance at the time. ${ }^{48}$ Setting up workshops for printing books was a costly enterprise, requiring appropriate instruments and technology. The following subsection examines the main features of intellectual protection during the Renaissance period.

\subsection{The Contrast of Contents}

At that time, the trends were associated with growth, but in different 'clothes' compared with the period after the Renaissance. This comparison highlights the process of how copyright transformed into a property right. The contemporary world is distinguished by the continuous technological developments that comprise the basic feature of modern times. ${ }^{49}$ The primary characteristic of the Renaissance was the growing volume of intellectual creations. Consequently, monopolies, relevant privileges and the necessity of creators' protections gradually emerged. In contemporary times, creators have sought to protect their online creations by using several digital licences. ${ }^{50}$

Moreover, the Renaissance period was characterised by a growth of interest in classical learning and values, the decline of feudal regimes, development of commerce and the application of inventions with effective potential, such as paper and printing. Throughout the Renaissance, creators needed protection for their creations, but there was no particular 'redress' or legitimate regime for intellectual protection.

The Statute of Monopolies (1623), which clarifies how monopolies are a crucial element in the relationship between governments and publishers by excluding creators' roles and rights, played a critical role in the examined evolution. This statute was an Act of the English Parliament and illustrates the first statutory expression of English patent law. ${ }^{51}$ Chris Dent argues that the Statute of Monopolies was a milestone in the history of patents, with ongoing importance. ${ }^{52}$ Further, it is worth noting that the monarch issued the patents involved to

47. V. Gillespie and S. Powell, A Companion to the Early Printed Book in Britain, 1476-1558 (Boydell \& Brewer Ltd, 2014).

48. P. Benedict, Graphic History: The Wars, Massacres and Troubles of Tortorel and Perrissin (Librairie Droz, 2007).

49. D. Landes, The Unbound Prometheus: Technological Change and Industrial Development in Western Europe from 1750 to the Present (Cambridge University Press, 2003); M. Givoni, 'Development and Impact of the Modern High-Speed Train: A Review', 26(5) Transport Reviews 593 (2006).

50. Q. Liu, R. Safavi-Naini \& N.P. Sheppard, 'Digital Rights Management for Content Distribution', 21 Proceedings of the Australasian Information Security Workshop Conference on ACSW Frontiers 49 (2003); V. Rosset, C.V. Filippin \& C.M. Westphall, 'A DRM Architecture to Distribute and Protect Digital Contents Using Digital Licenses', in Advanced Industrial Conference on Telecommunications/Service Assurance with Partial and Intermittent Resources Conference/E-Learning on Telecommunications Workshop (AICT/SAPIR/ELETE'05) (2005) 422.

51. A. Pottage and B. Sherman, Figures of Invention: A History of Modern Patent Law (Oxford University Press, 2010).

52. C. Dent, 'Generally Inconvenient: The 1624 Statute of Monopolies as Political Compromise', 33 Melbourne University Law Review 415 (2009) 
grant monopolies over specific enterprises to skilled individuals with new techniques. However, earlier English patent law was based on custom and common law, not on statute. ${ }^{53}$ Moreover, the Crown granted patents as a form of economic protection to ensure high industrial production; it was in response to this state of affairs that this statute emerged.

The issue was that these patents were the Crown's 'presents' or gifts, with no judicial review, oversight or consideration; consequently, no actual law developed around patents. ${ }^{54}$ This practice came from guilds groups that were manipulated by the Crown and in turn held monopolies over specific industries. ${ }^{55}$ Unlike the context of the current copyright and patent system, where privileges stem from creations, in the earlier period privileges were accepted as gifts from those who were ruling and were for the exclusive benefit of those who had governmental connections. Accordingly, Kostylo claims that: ' $[I]$ n contrast to modern copyright and patent, early privileges were conceived as a form of municipal favour (gratiae) and an exception to the law (priva lex) rather than the recognition of the author's inherent rights'. ${ }^{56}$ In addition, she points out, these privileges took various shapes, such as exclusive monopolies granting the creators the right to take advantage of their work or engage in other productive activity, and printing privileges bestowed on publishers or authors exclusive rights to print and sell a work. Hence, both privileges were granted in terms of manipulation rather than as the acknowledgement of the creator's production and affiliated IP rights. Moreover, these types of privileges would later be determined as patents for inventions and proto-copyrights, respectively. ${ }^{57}$

Thus, in the context of legitimacy, printing privileges and grants for automated inventions were practically identical. Further, according to Karjala, if patents are to be restricted in the current century to tangible objects and their operation by industrial procedures, it is to become progressively irrelevant as we steadily approach an information-as-product economy. ${ }^{58}$ Considering that the history of patents begins not with inventions but

53. C. MacLeod, Inventing the Industrial Revolution: The English Patent System, 1660-1800 (Cambridge University Press, 2002); A.L. Durham, Patent Law Essentials: A Concise Guide (Praeger, 4th ed., 2013).

54. T. Nachbar, 'Monopoly, Mercantilism, and the Politics of Regulation', 91(6) Virginia Law Review 1313 (2005).

55. A. Kieser, 'Organizational, Institutional, and Societal Evolution: Medieval Craft Guilds and the Genesis of Formal Organizations', 34(4) Administrative Science Quarterly 540 (1989); S. Epstein, Wage Labor and Guilds in Medieval Europe (UNC Press Books, 1991); G. Richardson, 'Guilds, Laws, and Markets for Manufactured Merchandise in LateMedieval England', 41(1) Explorations in Economic History 1 (2004).

56. J. Kostylo, Commentary on Johannes of Speyer's Venetian Monopoly (1469) (2008) Primary Sources on Copyright (1450-1900).

57. S. Bottomley, The British Patent System during the Industrial Revolution 1700-1852: From Privilege to Property (Cambridge University Press, 2014)

58. E.C. Walterscheid, 'Defining the Patent and Copyright Term: Term Limits and the Intellectual Property Clause', 7 Journal of Intellectual Property Law 315 (1999); D. Karjala, 'Distinguishing Patent and Copyright Subject Matter', 35 Connecticut Law Review 439 (2002); C. Long, 'Information Costs in Patent and Copyright', 90(2) Virginia Law Review 465 (2004). with royal grants of industrial monopolies in the Renaissance period, such as those granted by the English Crown, the origin of the idea that IP is a legal right is significant. Advocates claim that this radical change from monopoly privilege to legal property emerged solely in response to institutional and economic demands. ${ }^{59}$ Such history is relevant, as the concepts of copyright and patent were not very distinct.

Going back to Kostylo's argument about the lack of differentiation between copyright and patents, there are at least two explanations: legal and cultural. In legal terms, primary printing privileges for mechanical inventions had not produced a separate bureaucratic framework and continued to rely on the same system of discretionary privileges. A notable effort that shows the first attempt to differentiate these concepts was the 1710 enactment of the Statute of Anne, which introduced a legitimate framework for intellectual protection. ${ }^{60}$ The following section considers its significance as the first official regime for copyright law.

\subsection{Early Printing and Publishing in Europe}

Early printers were also publishers themselves, but by the sixteenth century there was a considerable increase in the number of printers. However, other individuals, who undertook the majority of costs and commercial risks, supported them financially. ${ }^{61}$ Many title pages of books from that time claim at the bottom that the work was printed by $\mathrm{xxx}$ for $\mathrm{xxx}$ (publisher or bookseller of the book). Occasionally, the publisher or bookseller was responsible for covering the costs of part of the supplies and equipment in the print shop and was usually sharing the income from the print run with the printer. ${ }^{62} \mathrm{It}$ is worth mentioning that several books were published under the auspices of a significant patron, such as the Pope, a monarch or a wealthy cardinal, signifying that the financial aspect of the printing process was of paramount importance. For example, Aldus Manutius was an Italian humanist who became a printer and publisher when he founded the Aldine Press at Venice. ${ }^{63}$ He made significant contributions to the enterprise of publishing, including inventing the italic form, introducing the use of the modern semicolon and the contemporary appearance of the comma and introducing inexpensive books in small formats. Additionally, and in relation to the costs of the printing process, it should be mentioned that Aldus Manutius issued various books with papal

59. A. Mossoff, 'Rethinking the Development of Patents: An Intellectual History, 1550-1800' (2006).

60. S. Elias and R. Stim, Patent, Copyright \& Trademark (Nolo, 2004).

61. J. Pasley, The Tyranny of Printers: Newspaper Politics in the Early American Republic (University of Virginia Press, 2002); A. Pettegree, The Book in the Renaissance (Yale University Press, 2010).

62. A. Fyfe, 'Information Revolution: William Chambers, the Publishing Pioneer', 30(4) Endeavour 120 (2006); J. Curran and J. Seaton, Power Without Responsibility: Press, Broadcasting and the Internet in Britain (Routledge, 2009); N. Goff, 'Direct-Response Bookselling: How It Died, Why It Is Alive Again, and Why It Will Become Even More Important in the Future', 27(3) Publishing Research Quarterly 259 (2011).

63. N. Barker, Aldus Manutius and the Development of Greek Script \& Type in the Fifteenth Century (Fordham University Press, 1992); E. Lupton, Thinking with Type (Chronicle Books, 2014). 
financial support. ${ }^{64}$ According to Sider, most printing projects were meant to make a profit, but not necessarily constantly regardless of total costs.

Moreover, many early printers had serious difficulties publishing, as printing was a capital-intensive and highly competitive business. ${ }^{65}$ It is to be expected that the publishers wanted to secure their investment and gains. Therefore, before printing a particular text, the printer would request permission from governments for an exclusive monopoly on printing that text. It is not surprising that privileges, monopolies and relevant revenues associated with intellectual creations and relevant efforts arose. ${ }^{66}$ However, it is obvious that the author's role was not so important in relation to the management of his works and potential agreements with publishers. Indeed, the author's role was relegated to the bottom in the hierarchy of interests in the context of trade, and the bilateral agreements between the publishers and the rulers highlight the emerging disadvantage of the author's role. According to Kretschmer, the rhetoric of author's rights has been broadly pushed by third parties (i.e. investors in creativity, rather than creators), who also turn out to be the chief beneficiaries of the extended protection. He argues, furthermore, that ever since the beginning the printing press environment has been extremely blurred, still showing traces of feudal features. ${ }^{67}$ In early times, the creators were mostly men, and therefore the pronoun he is used for reference.

The following subsection examines the relationship between Speyer, the publisher and the Venetian Government that granted exclusive privileges for printing in Venice. Hence, the concept of copyright developed from the exclusive privilege of printing rather than from a desire to protect the author's creation.

\subsection{Speyer's Monopoly and the English Printing Culture}

During the fifteenth century, the home of the first printing privileges was Venice. The very first publicly claimed copyright was decided by the rulers of Venice on 18 September 1469, shortly after the German Master Johannes of Speyer opened a printing shop there and started printing with the support of the rulers of the

64. H.-J. Martin, The History and Power of Writing (University of Chicago Press, 1995).

65. S. Sider, Handbook to Life in Renaissance Europe (Oxford University Press, 2007); B.R. Costas, Print Culture and Peripheries in Early Modern Europe: A Contribution to the History of Printing and the Book Trade in Small European and Spanish Cities (BRILL, 2012); A. Milward and B. Saul, The Economic Development of Continental Europe 1780-1870 (Routledge, 2013).

66. K. Maskus, Intellectual Property Rights in the Global Economy (Peterson Institute, 2000); P. Romer, 'When Should We Use Intellectual Property Rights?', 92(2) The American Economic Review 213 (2002); K. Idris, Intellectual Property: A Power Tool for Economic Growth (WIPO, 2003); E. Gresser, U.S. Share of World Intellectual Property Revenue - 39 Percent (2013).

67. M. Kretschmer, 'Intellectual Property in Music: A Historical Analysis of Rhetoric and Institutional Practices', 6(2) Studies in Cultures, Organizations and Societies 197 (2000); M. Kretschmer, L. Bently and R. Deazley, 'The History of Copyright History: Notes from an Emerging Discipline', in Privilege and Property: Essays on the History of Copyright (Open Book Publishers, 2010) 1.
Venetian Republic. This was the earliest European initiative where Speyer was granted an exclusive monopoly on printing in Venetian territories. Johannes Speyer was indeed bestowed with much more than merely a right to copy. He was given a five-year monopoly to print. In contemporary terms, this was a formal paradigm 'infant' industry protection. ${ }^{68}$ The practice of granting exclusive privileges to print in a particular city, to print a particular text or to print a particular category of texts spread instantly from Venice throughout the Italian states, and from there to France and England. ${ }^{69}$

Even though this monopoly has been addressed as the first acknowledged patent, setting in motion a long tradition of granting printing privileges in Europe, Speyer's monopoly does not seem to be something new or outstanding in the economic life and legal tradition of Venice. This is because Venetians may not have been the first to introduce printing into Italy, though they rapidly determined the significance of this new craft. ${ }^{70}$ Thenceforth, in the thirteenth century the Venetian people led Europe in their endeavours by granting monopoly rights to immigrants who brought new skills and qualifications to the city.

Certainly, during the fifteenth and sixteenth centuries the Venetian Government received over a thousand applications from specialists in diverse areas, among whom were the makers of soap, gunpowder, saltpetre and glass, tanners, miners and civil engineers. ${ }^{71}$ These applications cover every possible subject, from machines and tools for draining the marshes to poisons and windmills. Significantly, this new craft of printing flourished outside the guild structure and, consequently, in the absence of any administrative framework controlling and supervising this sort of commerce. As for the guilds, the rest of society usually judged these institutions as 'rivals' of the public good and not as laudable patterns for organising society on corporate lines. ${ }^{72}$ It is evident that printing and publishing commerce was not organised into a closed form until 1549. Hence, for the first eighty years of printing in Venice, relevant privileges continued to be granted occasionally and on an ad hoc basis. In this manner, distinction between commercial monopolies and proto-copyrights did not exist in early modern Venice.

68. G. Grossman and H. Horn, 'Infant-Industry Protection Reconsidered: The Case of Informational Barriers to Entry' (Working Paper 2159, National Bureau of Economic Research, February 1987); K. Head, 'Infant Industry Protection in the Steel Rail Industry', 37(3/4) Journal of International Economics 141 (1994); M. Shafaeddin, 'What Did Frederick List Actually Say? Some Clarifications on the Infant Industry Argument' (UNCTAD Discussion Paper 149, United Nations Conference on Trade and Development, 2000).

69. C. Hesse, 'The Rise of Intellectual Property, 700 B.C.-A.D. 2000: An Idea in the Balance', 131(2) Daedalus 26 (2002).

70. J. Kostylo, 'Sinking and Shrinking City: Cosmopolitanism, Historical Memory and Social Change in Venice' in Post-Cosmopolitan Cities: Explorations of Urban Coexistence (Berghahn Books, 2012) 170.

71. J. Weatherford, The History of Money (Crown Publishing Group, 2009).

72. J. Beinin, Workers and Peasants in the Modern Middle East (Cambridge University Press, 2001); J. Lucassen, T. De Moor \& J.L. van Zanden, The Return of the Guilds (Cambridge University Press, 2008). 
In sum, the practice of granting industrial privileges in early modern Italy constituted a crucial field in which new ways and methods arose concerning authorship and property. These developments formed the social and philosophical vocabulary of IP that foreshadowed its legal outline and adjustment as part of copyright tradition in the longer term. Let us now turn to England, a country with a long history concerning copyright and its growth. As England was also influenced by the rapid growth of intellectual creations in the Renaissance period, it acquired a well-established literary and printing culture.

First, in the sixteenth century the society of England was affiliated with Aristotle's views regarding property and the significance of individual evolution, and thus society was individualistic. ${ }^{73}$ Second, England has a long history of literary and printing culture, in which the concept of authorship could have been constructed. In addition, and as mentioned before, it is well known that printing had a revolutionary influence in Europe. England adopted the moveable sort of printing press from Germany during the Renaissance and instantly improved its publishing industry. ${ }^{74}$ Third, in terms of copyright protection, England has the longest legal tradition of copyright protection and was the first country to demonstrate a common law tradition of authors' rights. $^{75}$

\subsection{The Statute of Anne 1710}

Ronan Deazley claims that there were no fewer than thirteen failed efforts between 1695 and 1704 to accord a framework of statutory regulation for printing. ${ }^{76}$ Eventually, the Worshipful Company of Stationers and Newspaper Makers, usually known as the Stationer's Company, ${ }^{77}$ agreed to the Statute of Anne, which was enacted in the spring of 1710. Accordingly, there are advocates who argue that the passing of the Statute of Anne in 1710 is the seminal moment in copyright history. ${ }^{78}$ It is evident that, for the first time, regulations identified an author's - not the bookseller's - right to administer the reproduction of books. Further, the author's copyright as the exclusive right to administer the reproduction of books, according to the Statute of Anne, was valid for fourteen years since publication and could be renewed by the author for an additional seven

73. S.-H. Mun, Culture-Related Aspects of Intellectual Property Rights: A Cross-Cultural Analysis of Copyright (ProQuest, 2008).

74. British Academy, B.H. Harrison \& M.H.C. Gray, The Oxford Dictionary of National Biography: In Association with the British Academy: From the Earliest Times to the Year 2000 (Oxford University Press, 2004).

75. A. Barron, 'Copyright', 23(2/3) Theory, Culture \& Society 278 (2006).

76. R. Deazley, On the Origin of the Right to Copy: Charting the Movement of Copyright Law in Eighteenth Century Britain (Hart Publishing, 2004).

77. Ibid.; M. Rose, 'The Public Sphere and the Emergence of Copyright: Areopagitica, the Stationers' Company, and the Statute of Anne' in Privilege and Property: Essays on the History of Copyright (Cambridge: Open Book Publishers, 2010) 67.

78. M. Rose, Authors and Owners: The Invention of Copyright (Harvard University Press, 1995); P. Geller, 'Copyright History and the Future: What's Culture Got to Do with It', 47 Journal of the Copyright Society of the USA 209 (2000). years. ${ }^{79}$ By acknowledging the author's right to property in books and other printed material, the Statute of Anne set the foundation for the contemporary structure of copyright law.

Atkinson and Fitzgerald claim: "[T]he Act also resolved long-standing antagonism between publishers and parliamentarians, many of whom wanted to drive a dagger through the heart of the booksellers' monopoly'. ${ }^{80}$ The Statute of Anne was an agreement that stemmed from the publishers' willingness to regulate a chaotic market and politicians' willingness to strike at monopoly. Additionally, it is necessary to mention that the regulations, which were affiliated with the Statute of Anne, could not be described as friendly to booksellers. However, the most important transformation brought about by this Statute is in relation to what it does not legislate. It makes no provision whatsoever for the state arrangement of what could or could not be published. Additionally, the Statute of Anne argues about liberties that offending printers and booksellers have taken with authors and owners of intellectual creations who have realised that their books, inventions or writings were printed without their acquiescence. Deazley claims that: '[T]he basic plank of the Statute of Anne was then, and remains, a social quid pro quo. To encourage "learned men to compose and write useful books" the State would provide a guaranteed, if finite, right to print and reprint those works'. ${ }^{81} \mathrm{I}$ find support in this conclusion to contend that with the Statute of Anne a critical opportunity or bargain emerged involving authors, booksellers and the public. Deazley's statement correctly reflects the significance of the Statute of Anne as the first attempt at an effective equilibrium among the stakeholders of IP.

The scope of licensing under this statute was to regulate what might be said in print to control the publishers in the interests of good order. The primary aim of the Statute of Anne was to inspire further study and speech and to empower debates in the public sphere. Therefore, by entrusting the copyright of a printed work to the creator or author rather than the publisher or bookseller, the author is made responsible for the publishing and reproduction of his/her book; thus, the Statute reformulates the concept of copyright as a property right. That is, copyright, rather than being an advantage, benefit or 'gift' to authors, is the natural consequence that stems from their intellectual creativity. Hence, the Statute grants a legal framework to the public sphere, supporting a regime in which authors are invited to bring their intellectual creations or writings into the public forum. The rationale is that these are the

79. L. Bently, U. Suthersanen \& P. Torremans (eds.), Global Copyright: Three Hundred Years Since the Statute of Anne, from 1709 to Cyberspace (Edward Elgar Publishing, 1st ed., 2010).

80. B. Benedict and B. Fitzgerald, 'The Nineteenth Century: Liberty and Literary Property', in A Short History of Copyright (Springer International Publishing, 2014) 37.

81. R. Deazley, Rethinking Copyright: History, Theory, Language (Edward Elgar Publishing, 2006) 13-14. 
creations that stem from their authority, their learning and their considerations.

The old regime of licensing that strengthened the Stationer's Company was an opportunity for mutually beneficial discussions between the booksellers and the state. Accordingly, some proponents claim that the Statute of Anne offered a triple-path opportunity among creators/ authors, booksellers and the reading community. ${ }^{82} \mathrm{Spe}-$ cifically, authors were granted legal recognition and definite monopoly rights, booksellers were granted the chance to purchase and take advantage of these monopoly rights and the reading community was certain that after the end of the restricted term of protection the works would become free and open to everyone. By designating limitations, the Statute of Anne produced the literary commons, which is now known as public domain, and offered more social aspects in conjunction with intellectual creations. ${ }^{83}$ In other words, authors and booksellers began to enjoy mutual benefits.

\subsection{From 'Privilege' to Berne Convention}

As a cumulative consequence of the invention of the printing press by Gutenberg in 1436 and in conjunction with Speyer's monopoly and the Statute of Anne, the amount of publishing and copying worldwide developed considerably. ${ }^{84}$ Before the emergence of the printing press, booksellers used to copy authors' manuscripts by hand. ${ }^{85}$ After the introduction of printing, booksellers were able to copy authors' manuscripts at a much faster rate. Therefore, profits from the sale of books helped booksellers to recover the costs incurred on authors' manuscripts and the process of printing.

Because of the ease of printing, printing presses led to 'piracy'; there were 'pirate' booksellers who copied books already published by the 'lawful' booksellers. In addition, these 'pirate' booksellers could sell copied books at lower prices. This was because they were able to avoid paying for authors' manuscripts. ${ }^{86}$ It is reasona-

82. R. Deazley, 'Commentary on the Statute of Anne 1710', available at: www.copyrighthistory.org; M. Rose, 'Public Sphere and the Emergence of Copyright: Areopagitica, the Stationers' Company, and the Statute of Anne', 12 Tulane Journal of Technology and Intellectual Property 123 (2009).

83. L.R. Patterson, 'Understanding the Copyright Clause', 47 Journal of the Copyright Society of the USA 365 (2000); S. Morris and H.S. Shin, 'Social Value of Public Information', 92(5) The American Economic Review 1521 (2002); J. Boyle, 'The Second Enclosure Movement and the Construction of the Public Domain', 66(1/2) Law and Contemporary Problems 33 (2003); L.R. Goldberg et al., 'The International Personality Item Pool and the Future of Public-Domain Personality Measures', 40(1) Journal of Research in Personality 84 (2006); L.A. Fennell, 'Commons, Anticommons, Semicommons', in K. Ayotte and H.E. Smith (eds.), Research Handbook on the Economics of Property Law (2010).

84. I. Wallerstein, The Modern World-System I: Capitalist Agriculture and the Origins of the European World-Economy in the Sixteenth Century, with a New Prologue (University of California Press, 2011).

85. R. Rouse and M. Rouse, Manuscripts and Their Makers: Commercial Book Producers in Medieval Paris, 1200-1500, Vol. 1 (2000) 328; L. Mayer, Worlds Made Flesh: Chronicle Histories and Medieval Manuscript Culture (Routledge, 2004).

86. M. Everton, "'The Would-Be-Author and the Real Bookseller": Thomas Paine and Eighteenth-Century Printing Ethics', 40(1) Early American Literature 79 (2005); A. Johns, Piracy: The Intellectual Property Wars from Gutenberg to Gates (University of Chicago Press, 2010); W. Slaut- ble to expect that neither the 'lawful' booksellers nor the authors had any legal recourse against these 'pirate' booksellers. And it is obvious that from this point on the necessity of protection of the interests of the authors and publishers emerged. This necessity first emanated from the booksellers, whose economic interest was endangered by the 'pirate' booksellers. The booksellers successfully lobbied their respective sovereigns for protection in the form of an exclusive right, better known as a 'privilege' ${ }^{87}$ The privilege granted legitimate booksellers the exclusive right to print and sell specific authors' manuscripts for a limited time. In essence, the government bestowed upon the printer a limited monopoly. The sovereigns also benefited from this arrangement, because they could decide which booksellers would receive a privilege and which manuscripts were suitable for printing. ${ }^{88}$ The sovereign censored manuscripts that it believed would threaten the public order. ${ }^{89}$ The use of these privileges came to an end about two hundred years after they were introduced. ${ }^{90}$ There are three reasons or justifications for their demise: (a) Printers began to abuse their monopoly power, thereby angering their sovereigns in the process. In England, for instance, such abuses were one factor in the House of Commons' refusal to renew privileges. ${ }^{91}$ (b) As governments became more mature, the need for censorship began to diminish. (c) The authors became more active in arguing for protection of their own rights. ${ }^{92}$

The new system of protection that filled the vacuum left by the privilege system was a statutory form of protection that focused, for the first time, on the rights of the authors. ${ }^{93}$ With the Statute of Anne, the first statutory copyright for the protection of authors spread throughout Europe and the United States. However, a great number of authors' works crossed national boundaries and, as authors were unprotected in foreign countries, 'pirates' easily targeted their literary works. ${ }^{94}$ The authors from different countries acted to force governments to protect their works under an international

er, 'Upright Piracy: Understanding the Lack of Copyright for Journalism in Eighteenth-Century Britain', 16(1) Book History 34 (2013).

87. S. Yamada, 'Pirate' Publishing: The Battle over Perpetual Copyright in Eighteenth-Century Britain (Shoji Yamada, 2012).

88. M. Biagioli and P. Galison, Scientific Authorship: Credit and Intellectual Property in Science (Routledge, 2014).

89. B. Müller, 'Censorship and Cultural Regulation: Mapping the Territory', 22(1) Critical Studies 1 (2003); R. Birn, 'Book Censorship in EighteenthCentury: France and Rousseau's Response' (2005) 1 223; Anastasia Castillo, GRIN - Banned Books: Censorship in Eighteenth-Century England (2009).

90. K. Shao, 'Monopoly or Reward: The Origin of Copyright and Authorship in England, France and China and a New Criticism of Intellectual Property', 41 Hong Kong Law Journal 731 (2011).

91. A. O'Brien and M. Bosc (eds.), House of Commons Procedure and Practice, Second Edition 2009 (Yvon Blais, 2009).

92. N.J. Karolides, M. Bald and D.B. Sova, 120 Banned Books: Censorship Histories of World Literature (Checkmark Books, 2nd ed., 2011).

93. S. Ricketson, International Copyright and Neighbouring Rights: The Berne Convention and Beyond/Sam Ricketson and Jane Ginsburg (Oxford University Press, 2nd ed., 2006).

94. C. Bold, The Oxford History of Popular Print Culture (Oxford University Press, 2011). 
system and not just via domestic regimes. ${ }^{95}$ As the magnitude of piracy expanded, the scope of relevant activity regarding copyright protection from an international perspective also developed. More countries pursued the aim of settling copyright relations based on treaty. ${ }^{96}$

Material reciprocity was the core concept of the first international copyright treaties. ${ }^{97}$ In accordance with this concept, country one would grant country two's authors the same protection as country two would grant country one's authors. ${ }^{98}$ However, this regime was ineffective and complicated, ${ }^{99}$ and a number of countries maintained piracy as the focal theme of their international copyright relations. They declined to enter into any treaties, or if they did enter into such treaties they failed to abide by the terms.

The first attempt to protect foreign authors via the national treatment regime came from the decree of 1852. ${ }^{100}$ According to this treatment, country one granted authors from country two the same protection that country one granted its own authors. Thus, a national treatment framework is much easier to manage than a reciprocity framework, as courts need only interpret their own domestic copyright law. ${ }^{101}$ Therefore, any advances in domestic authors' rights in country one would automatically accrue to authors from country two.

Following the decree of 1852, a trend arose in Europe for better international protection of the authors' rights. The extension of copyright protection demonstrated additional support to authors' rights. As authors' rights triggered even more attention in domestic legislation, authors became an effective political group. Since the beginning of the movement, in the context of international copyright protection, two explicit principles competed for supremacy. First, the non-discrimination principle of domestic treatment preserves the probity of national regulations and ensures that foreign authors will be homogenised with local authors. Second, multilateral patterns ensure international consistency and thus increase the distribution of works of authorship globally.

In 1858, the first international Congress of Authors and Artists met in Brussels; the work of this group laid the

95. J. Ederington, 'International Coordination of Trade and Domestic Policies', 91(5) The American Economic Review 1580 (2001).

96. J. Jackson, The Jurisprudence of GATT and the WTO: Insights on Treaty Law and Economic Relations (Cambridge University Press, 2000).

97. V. Curzon, 'Non-Discrimination and the Rise of "Material" Reciprocity', 12(4) World Economy 481 (1989); K.A. Elliott and T. O Bayard, 'Reciprocity and Retaliation in U.S. Trade Policy' (Peterson Institute Press, 1994); E. Fehr and S. Gächter, 'Fairness and Retaliation: The Economics of Reciprocity', 14(3) The Journal of Economic Perspectives 159 (2000); H. Gintis, Moral Sentiments and Material Interests: The Foundations of Cooperation in Economic Life (MIT Press, 2005).

98. P. Yu, 'Currents and Crosscurrents in the International Intellectual Property Regime', 38 Loyola of Los Angeles Law Review 323 (2004).

99. B. Cammaerts, 'The Hegemonic Copyright-Regime vs. the Sharing Copyright Users of Music?', 33(3) Media, Culture and Society 491 (2011).

100. G. Gutu, 'Interpretative Dimensions on Object of Public Property', 6(1) Contemporary Legal Institutions 163 (2014).

101. M.A. Leaffer, Understanding Copyright Law (LexisNexis, 2010). groundwork for the drafting and signing of the Berne Convention. ${ }^{102}$ In addition, the decisions issued by the Congress impelled the gradual elimination of formalities, national treatment and domestic regulations. Thus, in accordance with the first draft of the Berne Convention, national forms were to work in cooperation with international forms, but the latter were to be applied via domestic regulations. Although the convention did not achieve every goal outlined at the first Congress in 1858, it illustrated the taking of a great step regarding international copyright protection. And despite the diverging views expressed by the participating countries, the last draft of the Berne Convention (1886) laid the groundwork for later developments concerning universality of an appropriate international copyright regime, which was introduced in earlier drafts. Therefore, the adoption by members of the WTO of the TRIPS Agreement further extended the Berne Convention's minimum standards to countries beyond the Berne Union. Therefore, the TRIPS Agreement is addressed in the following subsection.

\subsection{From Berne Convention to TRIPS Agreement}

The broadly differing patterns of protection and enforcement of IP rights, as well as the absence of a universal regime of regulations and disciplines to deal with the international trade in products, became a critical trend in the international trade relations. ${ }^{103}$ Eventually, the TRIPS Agreement was negotiated. It comprised an integral part of the multilateral trade negotiations under the Uruguay Round of the General Agreement on Tariffs and Trade (GATT). ${ }^{104}$ It covers copyright and related rights (i.e., the rights of performers, producers of sound recordings and broadcasting organisations); trademarks, including service marks; geographical indications, including appellations of origin; industrial designs; patents, including the protection of new varieties of plants; the layout designs of integrated circuits; and undisclosed information, including trade secrets and test data. A significant trait of the TRIPS Agreement concerns the extension of multilateral GATT dispute settlement as an appropriate regime for IP protection. This permits application of trade approvals by comprising, for instance, the suspension of concessions or other obligations. ${ }^{105}$

Sell and Prakash argue that, while the TRIPS Agreement represents the first comprehensive and enforceable

102. J. Ginsburg, 'International Copyright: From a Bundle of National Copyright Laws to a Supranational Code', 47 Journal of the Copyright Society of the USA 265 (2000).

103. D. Harris, 'TRIPS' Rebound: An Historical Analysis of How the TRIPS Agreement Can Ricochet Back against the United States', 25(1) Northwestern Journal of International Law \& Business 99 (2004).

104. P. McCalman, "Who Enjoys "TRIPs" Abroad? An Empirical Analysis of Intellectual Property Rights in the Uruguay Round', 38(2) Canadian Journal of Economics/Revue Canadienne D'économique 574 (2005).

105. S. Babovic and K.M. Wasan, 'Impact of the Trade-Related Aspects of Intellectual Property Rights (TRIPS) Agreement on India as a Supplier of Generic Antiretrovirals', 100(3) Journal of Pharmaceutical Sciences 816 (2011); G.D. Vita, 'The TRIPs Agreement and Technological Innovation', 35(6) Journal of Policy Modeling 964 (2013). 
global agreement on IP rights, it has been the subject of much criticism since its inception. ${ }^{106}$ The standard argument in support of TRIPS arises from the recognition of the modern importance of the knowledge economy and private IP as a crucial element of international commerce. ${ }^{107}$ According to Matthews, disputes regarding IP protection constitute significant non-tariff obstacles to commerce; thus, TRIPS is a consequence of the necessity of a robust multilateral scheme to substitute what was an ineffective patchwork of pre-existing IP conventions. $^{108}$ For the first time since GATT was launched in 1947, the Uruguay round of multilateral trade negotiations constituted an effort to harmonise international IP rights protection. By the end of these negotiations, participating states signed the TRIPS Agreement to regulate and protect trade-related aspects of IP rights. Additionally, the TRIPS Agreement brought IP into the trade regime overseen by the WTO and put in place a global minimum standard of intellectual protection that WTO members must follow. This covers copyrights, trademarks, industrial designs, geographical indications, patents, integrated circuit designs, trade secrets and anti-competitive contract restrictions. Suffice it to say that by globalising IP rights via the TRIPS Agreement, obstacles to trade were overcome. Various wider benefits to society are said to accrue from the imposition of temporary monopolies and other limitations that result from private IP rights. ${ }^{109} \mathrm{By}$ instituting legal protection, the disclosure of new knowledge and creativity is encouraged, and the significant costs associated with the creative process (such as with research and development) can be recouped and remuneration earned. Innovation is thus both rewarded and further promoted. Not only should the scope and reliability offered by a global intellectual property rights (IPR) regime stimulate domestic innovation, but the security offered to patent holders in the developed world and others can also encourage foreign direct

106. S. Sell and A. Prakash, 'Using Ideas Strategically: The Contest between Business and NGO Networks in Intellectual Property Rights', 48(1) International Studies Quarterly 143 (2004).

107. P. Van den Bossche, The Law and Policy of the World Trade Organization: Text, Cases and Materials (Cambridge University Press, 2008); B. Hoekman and M. Kostecki, The Political Economy of the World Trading System (Oxford University Press, 2009); A. Narlikar, M. Daunton \& R.M. Stern, The Oxford Handbook on The World Trade Organization (Oxford University Press, 2012).

108. D. Matthews, 'WTO Decision on Implementation of Paragraph 6 of the Doha Declaration on the Trips Agreement and Public Health: A Solution to the Access to Essential Medicines Problem?', 7 Journal of International Economic Law 73 (2004); D. Matthews, 'TRIPS Flexibilities and Access to Medicines in Developing Countries: The Problem with Technical Assistance and Free Trade Agreements', European Intellectual Property Review (2005); D. Matthews, 'From the August 30, 2003 WTO Decision to the December 6, 2005 Agreement on an Amendment to TRIPS: Improving Access to Medicines in Developing Countries?', Intellectual Property Quarterly (2006).

109. D. Lee, 'Understanding the WTO Dispute Settlement Process', Trade Politics (Psychology Press, 2004); J.L. Goldstein, D. Rivers \& M. Tomz, 'Institutions in International Relations: Understanding the Effects of the GATT and the WTO on World Trade', 61 International Organization 37 (2007). investment, technology transfer and licensing, and the diffusion of knowledge to the developing world.

What is more, the TRIPS Agreement represents a significant advance from previous agreements concerning IP rights in terms of monitoring, enforcement and dispute settlement capabilities. In addition, a TRIPS Council reviews domestic legislation and application of the accord. Therefore, its supporters see the TRIPS Agreement as representing an enforceable global regime of IP protection that plays an essential role in the contemporary global information society. The rewarding and encouraging of innovation spurs economic growth and enables technological evolution.

Since the TRIPS Agreement came into force, it has attracted increasing criticism from developing countries, academics and non-governmental organisations. Some of this criticism is against the WTO as a whole, but many advocates also regard the TRIPS Agreement as ineffectual policy. The TRIPS Agreement's wealth concentration effects (moving money from people in developing countries to copyright and patent owners in developed countries) and its imposition of artificial scarcity on the citizens of countries that would otherwise have had weaker IP laws are common bases for such criticisms.

For example, Drahos claims that: '[I]t was an accepted part of international commercial morality that states would design domestic intellectual property law to suit their own economic circumstances. States made sure that existing international intellectual property agreements gave them plenty of latitude to do so.' ${ }^{110}$ Further, Archibugi and Filippetti contend that the importance of TRIPS in the process of generation and diffusion of knowledge and innovation has been overestimated by both their supporters and their detractors. ${ }^{111}$ Claude Henry and Joseph E. Stiglitz argue that the modern IP global framework may impede both innovation and distribution and suggest reforms to empower the global dissemination of innovation and sustainable deployment. ${ }^{112}$ This article argues that OA practice is justified as a means of widening access to knowledge; the next part introduces the issues that will be developed further in the following chapters.

110. P. Drahos and J. Braithwaite, Information Feudalism: Who Owns the Knowledge Economy? (Earthscan, 2002) 38; D. Klein, The Strategic Management of Intellectual Capital (Routledge, 2009).

111. D. Archibugi and A. Filippetti, 'The Globalisation of Intellectual Property Rights: Four Learned Lessons and Four Theses', 1(2) Global Policy 137 (2010)

112. C. Henry and J. Stiglitz, 'Intellectual Property, Dissemination of Innovation and Sustainable Development', 1(3) Global Policy 237 (2010). 


\section{Open Access: A Means to Enhance Copyright Protection}

It is evident from the discussion in the preceding sections that scholars have been communicating thoughts, considerations, claims, research outcomes and examinations of these throughout the ages in a diversity of forms. For instance, lectures, discussions, essays, manuscripts, monographs, articles and books are among the most common ways of sharing intellectual ideas or scholarship. With the coming of the Enlightenment, the first scholarly periodicals, Philosophical Transactions of the Royal Society of London and Fournal des Scavans, appeared in 1665 from leading learned societies. ${ }^{113}$

Since that time, scholarly articles became a principal form for beneficial scholarly communication. ${ }^{114}$ Learned societies took authority and responsibility for editing and publishing scholarly journals during their early years. ${ }^{115}$ This trend continues; various contemporary scholarly societies publish some of the leading journals in a variety of science areas. However, after World War II, government investment in Western Europe and the United States in the field of scientific research increased the numbers of scholarly researchers who could communicate with their fellows. Simultaneously, it should be mentioned that the learned societies were slow to adapt to this instant flow of investment and that the representatives of the printing press industry entered the area in growing numbers to provide new titles in a variety of scientific areas.

The growing literature obligated subscribers of scholarly journals, such as academic libraries, government agencies, industrial research centres and individuals, to obtain access to scholarly data. ${ }^{116}$ However, the expenses associated with such access began to increase with the rise of electronic publication. ${ }^{117}$ In addition, journal publishers were forced to produce their content in two different forms - the hard copy journal and the electronic or digital version, hosted on a digital network. As the prices of scholarly journals surpassed costs, worries regarding maintenance of affordable access to this sort of literature began to amplify. What is more, the development of the Internet, and specifically the World Wide

113. D. Weber, Barbaros: Spaniards and Their Savages in the Age of Enlightenment (Yale University Press, 2005).

114. C. Bergstrom, 'Measuring the Value and Prestige of Scholarly Journals', 68(5) College \& Research Libraries News 314 (2007); C. Tenopir et al., 'Electronic Journals and Changes in Scholarly Article Seeking and Reading Patterns', 61(1) Aslib Proceedings 5 (2009).

115. J. Hopkins, 'The Role of Learned Societies in Knowledge Exchange and Dissemination: The Case of the Regional Studies Association, 1965-2005', 40(2) History of Education 255 (2011).

116. D. Boyd and K. Crawford, 'Critical Questions for Big Data', 15(5) Information, Communication \& Society 662 (2012).

117. F. Turner, From Counterculture to Cyberculture: Stewart Brand, the Whole Earth Network, and the Rise of Digital Utopianism (University of Chicago Press, 2010); D. Lyon, The Electronic Eye: The Rise of Surveillance Society - Computers and Social Control in Context (John Wiley \& Sons, 2013).
Web (WWW), introduced new terms, challenges and circumstances regarding scholarly communication. Therefore, I advocate the attachment of the printing press with digital or online platforms to follow up with the Internet, which in turn offers a contemporary way to publish.

Regardless of the emergence of the Internet, which promised the possibility of extending access to the scholarly literature via cost-effective ways, for-profit publishers instead of non-profit scholarly societies inhabit scholarly publishing to a greater extent and have increasingly consolidated their economic power. By using their collective power over pricing, for-profit publishers have firmly increased journal subscription prices, making it a struggle for academic libraries and other subscribers to benefit from their patrons' desire for access to up-to-date research.

A renowned author in the OA area, Michael Carroll, argues that as a result of frustrations over foregone opportunities to grow Internet diffusion of scholarly research and ever-rising journal prices, academic librarians, autodidacts and some academic leaders unified to initiate OA. ${ }^{118}$ Accordingly, Carroll argues that the principal goal of $\mathrm{OA}$ is quite simple, as within $\mathrm{OA}$ scholarly literature and relevant resources, information is freely available on the public Internet for end users and researchers of all kinds. ${ }^{119}$

$\mathrm{OA}$ is a useful innovation, even if there are minor obstacles to online availability of information that end users could enjoy while using scholarly journal articles. However, more significantly, copyright protection issues have emerged and should be considered. In this context, advocates argue that there are two ways scholars can make their articles accessible while simultaneously protecting copyright. They can do so by publishing either via the 'gold road' of OA, in which publications are freely available online to the public, or via the 'green road' of $\mathrm{OA}$ in a subscription-access journal, in which the author should self-archive an e-print of his/her work in an online OAR. ${ }^{120}$ Once an article is freely accessible by either method, it is indexed by search engines and is immediately locatable and retrievable by anyone with Internet access. ${ }^{121}$ Taking everything into account, the concept of $\mathrm{OA}$ is a response to current technological developments in conjunction with creative efforts that should be formulated and attached to modern copyright laws, appropriately.

118. M.W. Carroll, 'Movement for Open Access on Law, The', 10 Lewis \& Clark Law Review 741 (2006).

119. M.W. Carroll, 'Creative Commons and the Openness of Open Access', 368(9) New England Journal of Medicine 789 (2013).

120. S. Harnad, 'The Green Road to Open Access: A Leveraged Transition', in The Culture of Periodicals from the Perspective of the Electronic Age (L'Harmattan, 2007).

121. S. Cramond, Explainer: Open Access vs Traditional Academic Journal Publishers (2011) The Conversation. 


\section{Conclusions}

The article traced the historical development of the concept of copyright as property right. In addition, it discussed the transition from property of goods to property of ideas, using arguments that relied on old and modern philosophies about property.

To understand the significance of OARs, it is necessary to know the context of the debate. In modern times, a response to rapid technological evolution and relevant issues of intellectual protection is $\mathrm{OA}$, which comprises a collection of possible conditions and solutions (for instance, those offered from Creative Commons licences) under which the creator can protect his or her work and deliver free reproductions of copyright works. ${ }^{122}$ Considering the efforts by trade companies to develop new technologies for publishing should not neglect social benefits. Hence, OA practice can be considered as an instrument for social prosperity.

IP rights are a significant part of the regulatory environment designed to support economic development in the digital age. ${ }^{123}$ Current illustrations of growth in production are strongly related to investments in advances in IT (posts in Facebook, 'tweets' in Twitter, creating and uploading videos in YouTube and so forth) and correlate with the extent to which such technology-driven goods and services are disseminated throughout the economy. ${ }^{124}$ Thus, granting property rights in the fruits of innovative and creative endeavours has long been the policy instrument of choice to accomplish these objectives. ${ }^{125}$ All in all, highlighting IT as a basic contributor to economic growth demonstrates that $\mathrm{OA}$ practice, as one of its significant parts, should be considered a tool that supports dissemination of information resources that are distinguished by exclusive ownership.

122. J. Willinsky, 'The Nine Flavours of Open Access Scholarly Publishing', 49(3) Journal of Postgraduate Medicine 263 (2003).

123. K.E. Maskus and J.H. Reichman, International Public Goods and Transfer of Technology Under a Globalized Intellectual Property Regime (Cambridge University Press, 2005).

124. OECD, The New Economy: Beyond the Hype (2001).

125. J. Fairclough, Rethinking Construction Innovation and Research - A Review of the Government's R\&D Policies and Practices (2002) 96; K. Gangopadhyay and D. Mondal, 'Does Stronger Protection of Intellectual Property Stimulate Innovation?', 116(1) Economics Letters 80 (2012); K.J. Boudreau, 'Does Opening a Platform Stimulate Innovation? The Effect on Systemic and Modular Innovations', MIT Sloan Research Paper No. 4611-06 (2007). 